\title{
Protease and Lipase Activities of Pseudomonas Spp. Isolated from Pasteurized Milk
}

\author{
Hoda Mahrou 1
}

\begin{abstract}
Raw milk deteriorates in only a few days even when stored under refrigeration temperatures. Moreover, pasteurized and refrigerated milk has a shelf life of 7 to 10 days. Psychrotrophic bacteria have been recognized as a recurring problem in refrigerated storage and distribution of perishable food products. This study was performed to isolate, characterize and evaluate the prevalence of Pseudomonas spp. in pasteurized milk. Thirty five pasteurized milk samples were collected aseptically from different dairy shops, supermarkets and groceries in different areas in Sadat city, Menuofiya Governorate, Egypt and analyzed for total viable count and Pseudomonas spp. occurrence. Pseudomonas aeruginosa found to be the predominant from the Pseudomonas spp. followed by Pseudomonas fluorescens. The total viable count ( cfu per $\mathrm{ml}$ ) average \pm SD were $3.50 \times 10^{4} \mathrm{cfu} / \mathrm{ml} \pm$ 0.085. Out of ten Pseudomonas species isolates were examined to its proteolytic and lipolytic activity, two isolates had proteolytic activity, while three had lipolytic activity and five isolates had both.
\end{abstract}

Key words: Pseudomonas aeruginosa, Pseudomonas fluorescens, proteolytic and lipolytic activity.

\section{INTRODUCTION}

Milk has many nutritious qualities that make it an important part of children's diet. To produce the best quality milk and to achieve all the nutritious benefits of it, the highest quality raw milk must be obtained. Pasteurization and shelf stable milk products through Ultra High Temperature (UHT) continuous flow sterilization, are available (Goff and Griffiths, 2006). The conditions of heat treatment used for pasteurization depend on the final product, lower temperatures are used for refrigerated products and higher heat treatments are used for products stored at room temperature (USCFR, 2006). Psychrotrophic bacteria have been recognized as a recurring problem in the refrigerated storage and distribution of fluid milk and perishable dairy products for several decades. So, the psychrotrophic have received increased attention by investigators during recent years, because modern developments in the handling and transportation of milk have resulted in milk being held for longer period at refrigeration temperature before processing, manufacture or consumption.

\footnotetext{
${ }^{1}$ Department of Industrial Biotechnology, Genetic Engineering and Biotechnology Research Institute, Menuofiya University, Egypt. Received August 2, 2011, Accepted September13, 2011
}

Some psychrotrophic bacteria may grow at a temperature of $7^{\circ} \mathrm{C}$ although their optimum temperature is higher. Rapid cooling and cold storage of raw milk favor the growth of psychrotrophic bacteria in milk (Barbano et al., 2006). They become dominant microflora during cold storage of milk and their extracellular enzymes, particularly proteases and lipases, contribute to the spoilage of milk products (HantisZacharov and Halpern, 2007). Microbial growth and metabolism shorten the shelf life of milk by producing undesirable changes in aroma and taste attributes that influence consumer acceptability of the products (Fromm and Boor, 2004). Factors limiting milk stability are well established: bacterial contamination, inadequate packaging system and improper temperature control. Vulnerability of milk's fat and protein to physicalchemical alterations can also lead to deterioration, thus reducing its quality. Cromie (1991) reported the factors that influence the shelf life of pasteurized milk include the quality of the raw material, the binomial temperature/time pasteurization, resistant microorganisms to pasteurization (particularly psycrotrophics), the presence and activity of post pasteurization contaminants, the packaging system and storage temperature post pasteurization which had the greatest impact on the stability of the product. Shelf life of pasteurized milk . Extra cellular lipolytic enzymes produced from psycrotrophics can produce deteriorate effects as rancid flavours and odours in milk and dairy products that make a subsequent reduction of shelf-life and the products become unacceptable to consumers(Downey,1980). The proteolytic enzymes produced by psycrotrophics in milk are more powerful in its action on milk proteins than that naturally present in milk and that produced by leucocytes even if present by great amount(Grieve and Kitchen, 1985). Pseudomonas spp. produces a large number of extracellular toxins, which include phytotoxic factor, pigments, hydrocyanic acid, proteolytic enzymes, phospholipase and enterotoxins. Exotoxins are the most factor responsible for pseudomonas spp. pathogenicity because it can produce leucopoenia, circulatory collapse, necrosis of liver, pulmonary odema, hemorrhage and kidney tubular necrosis. The enterotoxin produced is responsible for diarrhea disease. Higher temperature for shorter times were less effective 
in destruction of the Pseudomonas spp. than that of temperature for longer times because the condition created in the milk at high temperatures may favor of injured cells (Cousin,1982).Generally they are considered incapable of surviving pasteurization and they may be post-processing contamination. Although, they can cause gastroenteritis if ingested in large number(>106), but also the food would be clearly spoiled before such numbers would reached (Johnson,1990). Moreover, its presence in milk and its products was considered as a possible indicator of fecal contamination. Also Pseudomonas aeruginosa has been implicated in epidemics of moderate to severe diarrhea in children in the form of enteric fever (Todar, 2002).

This study aimed to explain the occurrence of Pseudomonas species contamination and observation of the proteolytic and lipolytic behavior of it in the pasteurized milk sold in Sadat city, Menuofiya Governorate, Egypt.

\section{MATERIALS AND METHODS}

Thirty five samples of pasteurized milk were collected randomly from various local milk supermarket in different areas in Sadat city, Menuofiya Governorate, Egypt. Collected samples were examined for total viable cells and bacteriologically for occurrence and behavior of Pseudomonas organisms. Psychrotrophic isolates were obtained from pasteurized milk by pour plating appropriately diluted sample using nutrient agar. Incubation was done at $7^{\circ} \mathrm{C}$ for 10 days (Cousin et al, 2001). The psychrotrophic isolates were subjected to biochemical characterization after activating the culture in nutrient broth at $37^{\circ} \mathrm{C}$ for $24 \mathrm{~h}$ (Barrow and Feltham,1993).

\section{Identification of Pseudomonas isolates}

The representative suspected colonies were purified and then identified according to Bergey's Manual of Systemic Bacteriology (1984) and API 20NE.

\section{Determination of the proteolytic and lipolytic activities of Pseudomonas species}

Ten strains belonging to Pseudomonas species isolated previously from pasteurized milk samples were investigated for their proteolytic and lipolytic activities as described by Harrigan and McCance (1976).

\section{Preparation of isolates}

Pseudomonas isolates were subcultured onto nutrient agar plates and incubated at $30^{\circ} \mathrm{C}$ for $24 \mathrm{~h}$. Pure cultures were inoculated into nutrient broth and incubated overnight at $30^{\circ} \mathrm{C}$ prior to testing.

\section{Proteolytic activity using skim milk agar}

Overnight cultures were spot inoculated onto milk agar, standard plate count agar supplemented with $10 \%$ sterile skim milk. The inoculated plates were incubated at $20^{\circ} \mathrm{C}$ and $4^{\circ} \mathrm{C}$ for 10 days. The presence of transparent zones around the spots was recorded as positive strains referring to protease production, and subsequently flooded with $10 \% \mathrm{v} / \mathrm{v}$ acetic acid solution. Clear zone around the colonies after one minute exposure were regarded as positive (Harrigan and McCance, 1976).

\section{Lipolytic activity}

Lipolytic counts (LP) were determined using nutrient agar (NA) containing tributyrin. The medium was prepared $10 \mathrm{~g}$ of tributyrin and $28 \mathrm{~g}$ of NA. Plates were incubated at $20^{\circ} \mathrm{C}$ and $4^{\circ} \mathrm{C}$ for $72 \mathrm{~h}$ determine viable lipolytic counts, and lipolytic activity was determined by measuring clear zone around each colony (Harrigan and McCance, 1976).

\section{RESULTS AND DISCUSSION}

\section{Incidence of Pseudomonas spp. among the examined samples:}

The samples showed an average \pm SD of total viable count of $3.50 \times 10^{4} \pm 0.085 \mathrm{cfu} / \mathrm{ml}$. According to Prevention of Food Adulteration Act (PFA, 2007) total plate count of pasteurized milk should not exceed $30,000 \mathrm{cfu} / \mathrm{ml}$. However it was observed that all the standard plate count plates were characterized by the predominance of typical small circular entire smooth and shining uncolored colonies. Furthermore, only this type of colony was evident in the plates used for taking psychrotrophic count (Table 1). The Pseudomonas spp. count (cfu per $\mathrm{ml}$ ) average \pm SD was $1.5 \times 10^{2} \pm 0.01$ among different samples, and the isolates were subjected to bacteriological examination (Table 2 ) such as lactose negative and blue-black and greenish bright dark colonies are lactose positive as a result of incubation during 48 hours at $30^{\circ} \mathrm{C}$. Among these, with the lactose negative ones are continued to be studied on and these colonies were applied oxidation-fermentation test. Pseudomonas react oxidative. Among the same samples catalase $(+)$, motility $(+)$ and oxidase $(+)$ colonies were studied on growth at $4{ }^{\circ} \mathrm{C}$ and $41^{\circ} \mathrm{C}$ have been the first taken into consideration. So, Pseudomonas, which incubated into yeast extract medium were left at $4^{\circ} \mathrm{C}$ for 7-10 days and at $41^{\circ} \mathrm{C}$ for 24 hours respectively (Mickova et al.,1989).

The results showed that 10 samples were positive for occurrence of Pseudomonas spp., with a percentage of $26.7 \%$. Identity of the isolates were confirmed by using API 20NE for detection and isolation of Pseudomonas spp. as Pseudomonas aeruginosa (7 isolates) and Pseudomonas fluorescens (3 isolates). Many investigators indicated that some Pseudomonas spp. could survive heat treatment used in pasteurization of 
Table 1. Prevelance and count of Pseudomonas spp. in examined pasteurized milk samples

\begin{tabular}{ccccccc}
\hline & \multicolumn{2}{c}{ Positive Samples } & & & \\
\cline { 2 - 3 } No. of samples & No. & $\%$ & Min. & Max. & Mean $\pm \mathrm{SD}^{*}$ \\
\hline 35 & 10 & 28.5 & $1.5 \times 10$ & $2.5 \times 10^{3}$ & $1.5 \times 10^{2} \pm 0.01$ \\
\hline \hline
\end{tabular}

* $\mathrm{SD}=$ Standard deviation.

\section{Table 2. The Bacteriological Examination of Pseudomonas spp. In examined pasteurized} milk samples

\begin{tabular}{|c|c|c|c|c|c|c|c|c|c|c|c|}
\hline $\begin{array}{c}\text { No. of } \\
\text { isolates }\end{array}$ & Catalase & Oxidase & $\mathbf{O} / \mathbf{F}$ & $\begin{array}{c}\text { Lactose } \\
\text { Fermention }\end{array}$ & Motility & MR & $\mathbf{V P}$ & $\begin{array}{c}\text { Citrate } \\
\text { Utilization }\end{array}$ & $\begin{array}{c}\text { Gelatin } \\
\text { Hydrolysis }\end{array}$ & $\begin{array}{c}\text { Indol } \\
\text { Production }\end{array}$ & $\begin{array}{c}\text { Nitrate } \\
\text { Reduction }\end{array}$ \\
\hline 1 & + & + & $\mathbf{O}^{+} / \mathbf{F}^{-}$ & - & + & - & - & + & + & - & + \\
\hline 2 & + & + & $\mathrm{O}^{+} / \mathrm{F}^{-}$ & - & + & - & - & + & + & - & + \\
\hline 3 & + & + & $\mathrm{O}^{+} / \mathrm{F}^{-}$ & - & + & - & - & + & + & - & + \\
\hline 4 & + & + & $\mathrm{O}^{+} / \mathrm{F}^{-}$ & - & + & - & - & + & + & - & + \\
\hline 5 & + & + & $\mathrm{O}^{+} / \mathrm{F}^{-}$ & - & + & - & - & + & + & - & + \\
\hline 6 & + & + & $\mathrm{O}^{+} / \mathrm{F}^{-}$ & - & + & - & - & + & + & - & + \\
\hline 7 & + & + & $\mathrm{O}^{+} / \mathrm{F}^{-}$ & - & + & - & - & + & + & - & + \\
\hline 8 & + & + & $\mathrm{O}^{+} / \mathbf{F}^{-}$ & - & + & - & - & + & + & - & + \\
\hline 9 & + & + & $\mathrm{O}^{+} / \mathrm{F}^{-}$ & - & + & - & - & + & + & - & + \\
\hline 10 & + & + & $\mathrm{O}^{+} / \mathrm{F}^{-}$ & - & + & - & - & + & + & - & + \\
\hline
\end{tabular}

milk (Abad et al.,1993). Incidence of Pseudomonas aeruginosa in pasteurized milk has been reported by Kumaresan and Annal Villi (2008). According to them, post processing contamination led to the predominance of heat sensitive Pseudomonas spp.in pasteurized milk.

Quality defects in pasteurized milk are most often the result of microbial contamination, growth and spoilage. Microbial defects usually become evident in the finished product through shelf-life evaluations or consumer complaints. Post-pasteurization contamination with psychrotrophic spoilage bacteria is most detrimental. In most cases, product contamination is the result of insufficient cleaning and sanitation of the processing equipment and plant environment. Practices that are being followed in the dairy processing unit would have singled out psychrotrophics as the major category of spoilage organism (Alatossava and Alatossava, 2007).

The proteolytic and lipolytic activities of Pseudomonas species

The high spoilage potential of Pseudomonas species is not only because of its ability to multiply at refrigeration temperatures but also because of their ability to produce thermostable proteases and lipases (Sorhaug and Stepaniak, 1997).The importance of proteases and lipases, which causes bacterial virulence, were proven in several studies. However, there was less study in the protease and lipase activities of Pseudomonas spp.

This study showed that the Pseudomonas spp. isolates are not showed proteolytic and lipolytic activities at $4^{\circ} \mathrm{C}$, while at $20^{\circ} \mathrm{C}$ the Pseudomonas aeruginosa and Pseudomonas fluorescens isolates shown both of these activities which illustrated in (Table 3) .Two isolates were positive for proteolytic ; three lipolytic and five isolates for both proteolytic and lipolytic. This finding agrees with the findings of Dogan and Boor (2003) and Alatossavaand Alatossava (2006) .

Psychrotrophics were implicated in many defects in milk and dairy products which are a problem resulting from prolonged refrigeration storage (Swart et al. 1989; Garg, 1990) and distribution of perishable food products. Pseudomonas species have been implicated in the spoilage of processed milk kept under chilled condition because of their capacity to multiply under refrigeration with the production of thermostable proteases and lipases (Rajmohan et al., 2002) so Pseudomonas spp. plays an important role in milk spoilage.

$\begin{aligned} & \text { Table 3. Proteolytic and lipolytic activities of Pseudomonas } \\
& \text { milk samples }\end{aligned}$
\begin{tabular}{lcccc} 
Pseudomonas isolates & $\begin{array}{c}\text { No.of tested } \\
\text { isolates }\end{array}$ & $\begin{array}{c}\text { Positive } \\
\text { protyolytic } \\
\text { isolates }\end{array}$ & $\begin{array}{c}\text { Positive lipolytic } \\
\text { isolates }\end{array}$ & $\begin{array}{c}\text { Positive protyolytic } \\
\text { \&lipolytic isolates }\end{array}$ \\
\hline $\begin{array}{c}\text { Pseudomonas aeruginosa } \\
\text { Pseudomonas fluorescens } \\
\text { Total }\end{array}$ & 7 & 1 & 2 & 4 \\
& 10 & 1 & 1 & 1 \\
\hline
\end{tabular}




\section{Conclusion}

The previous information indicated that psychrotrophics are still inevitable because they are widely distributed in nature, withstand sanitizers and can liberate heat stable enzyme causing spoilage of food and some of them considered as food borne pathogens. This knowledge increasing attention toward the way by which the restriction of these microorganisms must be done. In this study the results cleared that after pasteurized 10 samples from 35 samples were positive for occurrence of Pseudomonas spp., with a percentage of $26.7 \%$ that may be due to insufficient pasteurization or the post contamination by this genus and the temperature which milk and dairy products are exposed influences the type of microorganisms that will grow in them. As dairy equipment and utensils constitute the major source of many types of psychrotrophics in milk, so special attention should be considered in their cleaning and sanitation to produce milk of low bacterial count or even completely free of psychrotropics bacteria.

\section{REFERENCES}

Abad, P., Villafafila, A., Frias, J. D. and RodriguezFernandez, C. (1993): Extracellular lipolytic activity from Pseudomonas fluorescence biovar1 (Pseudomonas fluorescencs $\mathrm{Ncl}$ ) Milchwissenschaft, 48(12):680-683.

Alatossava, M. andAlatossava, T. (2006). Phenotypic characterization of raw milkassociated psychrotrophic bacteria.Microbiol. Res. www.sciencedirect.com.

Alatossava,P.M. and Alatossava, T. (2007). Antibiotic resistance of raw-milk associated psychrotrophic bacteria. Microbiol Res. , 162:115-123.

Barbano, D.M., Ma, Y. and Santos, M.V.( 2006). Influence of Raw Milk Quality on Fluid Milk Shelf Life. Journal of Dairy Science, 89, E15-E19.

Barrow, C.J. and Feltham,R.K.A. (1993). Cowan and Steel's Manual for Identification of Medical Bacteria. Third edition. Cambridge University ,Press, London, 332p.

Bergey's manual of Systemic Bacteriology (1984) : Williams and Wilkins, Baltimore London, Vol.(1).

Cousin, M. A. (1982): Presence and activity of psychrotrophic microorganisms in milk and dairy products: A review. J. Food Prot.,45:172-207.

Cousin, M,A., Jay, J.M and Vasavada, P.C. (2001). Psychrotrophic microorganisms In Compendium of methods for microbial examination of foods, 4th ed. APHA, Washington DC, pp.159-164.

Cromie, S.J. (1991). Microbiological aspects of extended shelf life products. Aust J Dairy Technol., 46, 101-104.
Dogan, B. and Boor, K J. (2003). Genetic diversity and spoilage potentials among Pseudomona ssp. isolated from fluid milk products and dairy processing plants. Appl. Environ. Microbiol.,69: 130-138.

Downey, W. K. (1980).Flavor impairment from pre- and post manufacture lipolysis in milk and dairy products. A review, J. Dairy Res., 47:237-252.

Fromm, H.I. and Boor, K.J. (2004). Characterization of pasteurized fluid milk shelf-life attributes. J Food Sci., 69, 207-214.

Garg, S. K. (1990): Psychrotrophs in milk. A review. Ind. J. Dairy Sci., 43, (3): 433-440.

Goff, H.D. and Griffiths, M.W. (2006). Major advances in fresh milk and milk products. J. Dairy Sci., 89: 11631173.

Grieve, P. A. and Kitchen, B. J. (1985). Proteolysis in milk: the significance of proteinases originating from milk leucocytes and a comparison of the action of leucocyte bacterial and natural milk proteinases on casein. J. Dairy Res., 52:101-112.

Hantsis-Zacharov, E., Halpern, M. (2007). Cultural psychrotrophic bacterial communities in raw milk and their proteolytic and lipolytic traits. Appl. \& Environ. Microbiol., 73, 7162-7168.

Harrigan, W. F. and MacCance, M. E. (1976): Laboratory Methods in Food and Dairy Microbiology. Academic Press, London.

Johnson, K.M. (1990). B.cereus food borne illness- an update. J. Food Prot., 47(2):145-153.

Kumaresan, G.and Annalvilli, R.(2008).Incidence of Pseudomonas species in pasteurized milk.Tamilnadu $\mathrm{J}$ of Vet .and Animal Sci., 4:56-59.

Mickova, V., Lukasova, J., and Konencny, S. (1989). Pseudomonas aeruginosa in raw and pasteurized milk, Veter, Med.(Praha), 34 : 411.

Rajmohan, S., Dodd, C.E.R. and Waites, W.M. (2002). Enzymes from the isolates of $P$. fluorescens involved in food spoilage. J. Appl. Microbiol., 93: 205-213.

Sorhaug, T. and Stepaniak. (1997). Psychrotrophs and their enzymes in milk and dairy products. Trends Food Sci. Technol., 8: 35-41.

Swart, G. J., Jooste, P. J. and Mostert, J. F. (1989): The occurrence and seasonal distribution of psychrotrophic and certain mesophilic bacterial types in the bulk milk supply of the Pretoria area. Suid- Afrikaanse. Tydskrif Vir Suiwelkunde, 21 (1): 1-8, Dairy Sci.Abst., 51: 6441.

PFA, (2007) .The Prevention of Food Adulteration Act, 1954 (Second Amendment) Rules. Universal Law Publishing Co. Pvt. Ltd. 350p.

Todar, K. (2002): Pseudomonas aeruginosa. In: Todar's Online Textbook of Bacteriology.

USCFR. (2006). United States Code of Federal Regulation. How heat treatment affect the final product. C.F.R. Title 21, part 131, Section 112. 


\section{الملخص العربي}

\section{النشاط التحللي للبروتين و الدهن لبكتريا Pseudomonas spp المعزولة من اللبن المبستز}

$$
\text { هدي ححروس }
$$

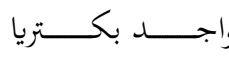

م وفي 10 10عينات من العينات تحت الدراسة

وفيها كانت بكتريا Pseudomonas aeruginosa هي السائدة

ويليها بكتريا Pseudomonas fluorescens وكـان متوسط العد

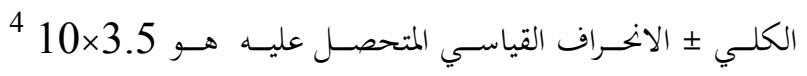

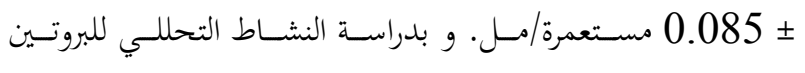

والدهن لهذه العشرة عزلات التابعة لجنس . Pseudomonas spp وجـد عزلتـان موجبة لتحلل البروتين فقط و 3 عزلات محللة للدهن

$$
\text { فقط و } 5 \text { عزلات محلله للبروتين و الدهن معا. }
$$

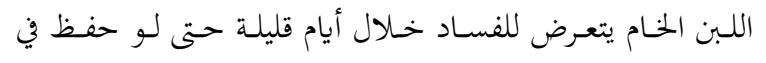

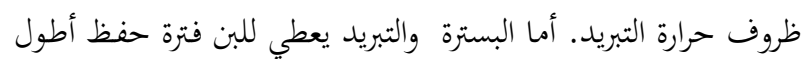

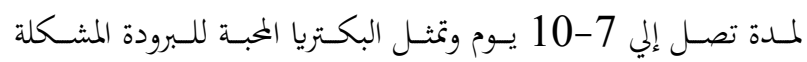
الأساسية في اللبن المبستر.

تهـدف هـذه الدراسـة إلي عزل و تقـدير البكتريا المحبة للمبرودة في

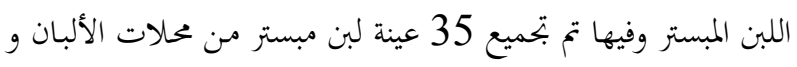

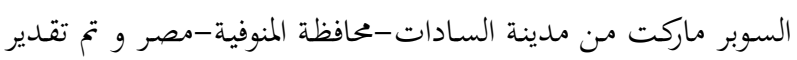

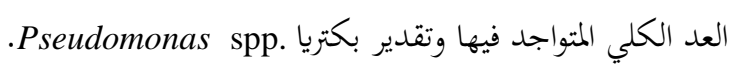

